\title{
EVALUATION OF THE TOTAL QUALITY FACTORS BASED ON DEMING MANAGEMENT MODEL IN OIL INDUSTRY IN LIBYA - AN EMPIRICAL STUDY
}

\author{
Redha M Elhuni* and M Munir Ahmad** \\ *Libyan Petroleum Institute, Libya **School of Science and Engineering, Teesside University, \\ Middlesbrough, UK
}

\begin{abstract}
The purpose of this paper is to investigate the quality management dimensions, based on Deming Management Model, in Oil industry in Libya. Questionnaire, semi structured interview and open interview were used to collect data from random sample of 42 qualityrelated managers from the Libyan Oil industry. Forty-five questionnaires were provided by hand to quality-related managers from the Libyan Oil companies. A total of 42 were returned sufficiently completed, that gave us a response rate of approximately $93.33 \%$.

The regression analysis indicated that these organizations implement total quality management practices. The findings suggest that an integrated approach is required to implement the total quality management practices in order to realize strategic quality objectives.

This research is subject to the normal limitations of survey research. The data is based on individual opinion of quality related managers, which may bring in some bias. Further research needs to be done to advance our knowledge and to further support the findings. For instance, a larger sample size and more items per Deming principle may be used in future studies to duplicate these results and to increase the internal consistency of the scales. Deming Management Model is applied to one industry in this study. Therefore, to establish the generalization of the Model within the context of Libya, it needs to be tested in other industries setting, both in public and private sectors.

The study extends the applicability of the Deming Management Model to a new industry and country. Collectively, the results of the research provide more understanding of issues relating to quality management in developing countries and a framework for enhancing organizational effectiveness. Therefore, the research can make a useful contribution.
\end{abstract}

Keywords: Total quality management; TQM; Libya oil and gas sector; Deming management model. 


\section{INTRODUCTION}

The change over to TQM is currently very popular in the Libyan Oil and Gas companies (LOGCs) as a method to improve productivity, eliminate waste, reduce operation costs, and enhancing customer satisfaction. Although it is a relatively new and revolutionary approach in Libya, more and more companies are committing themselves to invest in TQM in the long term.

The problem however, is that most LOGCs today seem to be paying only lip service to TQM implementation. To what extent are executives in LOGCs aware of the impending pressures on them to conform to quality standards? Even those who may be aware, what practical steps are they take to ensure conformity?

In fact, TQM is not well defined in Libya, but is still an ambiguous concept. However, the major TQM implementation practices in LOGCs could be summarized as: Using various kinds of quality management tools such as the Quality control (QC) seven tools and statistical process control (SPC) in practice; implementing QC circles activities; analyzing and identifying quality-related costs; emphasizing quality inspection; In the meantime, many people working in LOGCs accepted education and training on quality management system such ISO.

A comprehensive review of literature indicated that the research on Libya's TQM domain, however, has not attracted much attention. As a result, couple research has been conducted in construction and manufacturing field. However, no research has been conducted in Oil and Gas Sector that is progressing at a gallop pace.

Commercial oil was discovered in Libya in 1957. Today, Libya ranks 17 th in the global oil production. Since 1986, the Libyan oil and gas industry has been managed by the (NOC) which is the national oil company of Libya.

The objective of the study is to assess the TQM practices of LOGCs and suggest measures for improving their competitiveness. The study was undertaken to address the lack of empirical findings concerning application of fundamentals of total quality management within Libyan Oil and Gas Companies (LOGCs).

The results will provide an objective insight to LOGCs to plan necessary steps of action to achieve and sustain quality based competitive advantage. The study will generate information that will be useful for organizational directors in evaluating TQM practices in their own companies, in Libya, using Deming Management Model to enhance organizational 
performance. The study would add to the continued efforts toward theory building, enhancement, wider applicability, and provide support in consolidation of knowledge.

\section{LITERATURE REVIEW}

The existing quality management philosophy has been strongly influenced by the thoughts of Deming, Juran, Crosby, Feigenbaum, and Ishikawa. Deming (1986) 14 points, Juran (1988) trilogy and 10 steps, Crosby 14 steps to quality improvement, as identified by Brocka and Brocka (1992), and Feigenbaum (1983) approach of total quality control are essential elements of a quality strategy. The holistic approach to quality management is vital for competitiveness.

Deming Management Model is based on the theory of Deming that was formulated by Anderson et al (1994). Deming Management Model encompasses the TQM philosophy articulated in a prescriptive set of 14 points. The 14 points in Deming Management Model are essential statements, which lay down the foundation and action plan for intra-organizational and inter-organizational behaviour. Adoption of these 14 points offer organizations with requisite strength and energy and facilitate organizations to overcome obstacles in achieving performance excellence.

The extensive readings of published materials by W. Edwards as well as other quality experts, have developed seven constructs, these seven constructs is displayed in Table 1. Insights from the readings were further developed via a three-round Delphi study using academic and practitioner experts to identify the concepts underlying Deming's 14 points (Deming, 1986). The research team then clustered these concepts into seven constructs to represent the content of the Deming management method.

The framework of Deming Management Method expresses effectiveness of the model through concerted leadership efforts toward establishment of cooperative and learning organization systems that facilitates achievement of efficient process management. The realization of process management practices enables organizations to achieve customer satisfaction through continuous improvement and employee fulfillment. The theoretical framework based on the seven constructs expressing Deming Management Method is shown in (Fig. 1).

There have been two empirical examinations of the Deming management model in the literature. First, Anderson et al (1995), using measures identified from the world-class manufacturing research project (Flynn, Schroeder, \& Sakakibara, 1994), found exploratory 
support for most of the hypothesized relationships. Second, Rungtusanatham et al (1998) replicated the first study using manufacturing facilities located in Italy. Both the Anderson et al (1995) and Rungtusanatham et al (1998) studies supported most of the relationships in the Deming management model. However, both studies suggested that additional testing of the Deming management model in other industries to confirm its generalizability, and applicability across sectors, countries, industries, employee groups and time periods was necessary. Other researchers also argued that refinement efforts through testing of this theory in different contexts would contribute toward better understanding, and assist in knowledge consolidation (Sousa and Voss, 2002).

Mann and Kehoe (2004) examined the process of TQM implementation in 21 UK-based organisations with at least two years' experience of TQM and concluded that the implementation processes used were largely diverse and there appeared to be no one dominant approach. The data led them to conclude that there appeared to be no optimum approach to implementation. Newall and Dale (2002) concluded from their study of eight UK organisations (seven were manufacturers). They identified six phases: awareness; education and training; consolidation; planning, problem identification and problem solving; implementation of quality improvement plans; and assessment.

\section{DEVELOPMENT OF HYPOTHESES}

Deming Management Method Model has identified seven constructs. To develop hypotheses, these seven constructs are examined separately to explore various dimensions underlying these constructs. Review of literature has been done to find support for these constructs.

Visionary Leadership: The key role top management commitment and leadership plays in driving company-wide quality management has been recognized by practitioners and researchers as one of the major factors for achieving successful quality performance (Deming, 1986; Flynn et al., 1994; Juran, 1988; Puffer and McCarthy, 1996). The top management element is the first step for successful implementation of TQM through leadership strategy and policies; quality planning; management by fact; and managing innovation. Top Management Commitment \& Leadership encompasses the role of top management in defining a vision, mission, strategic objectives, and shared values for the organization's growth and development. In quality management context, the leaders need to emphasize the importance of transformation through open communication to achieve a shared approach to the change. Quality Gurus stressed that leadership is vital for effective implementation of total quality management initiatives. Zairi (1994) argued that in TQM 
environment, leaders focus on employee autonomy, recognition, coaching, and development. Rao et al., (1999) noted that top management is responsible for quality leadership and providing support to achieve superior performance. Pierce and Niewstrom (2000) highlighted the importance of leadership in the process of ascending to world-class status, and emphasized the need for leadership to establish a high-performance culture, highperformance delivery processes and services in support of this objective.

Internal and external cooperation: Internal and external cooperation is the propensity of the organization to engage in non-competitive activities internally among employees and externally with respect to suppliers. Internal cooperation is about teamwork, unity of purpose, mutual trust and respect for all, participation at all levels and shared approach throughout the organization. The internal cooperation construct is like human resource concept which included items such as communications, employee involvement, training and education, recognition of support for quality objectives, and employee satisfaction (e.g., Cook \& Verma, 2002).

The external cooperation concept, many argue that internal customer-suppler relationship is the basic principle behind this approach. Oakland (2000) referred to this as a series of internal supplier-customer chains contributing to the company-wide quality involvement in the company.

The suppliers' interaction with customers provides opportunities for improvement of products, services, and processes. Rao et al (1999, p. 1052) noted that quality-oriented companies pursue a proactive strategy in developing long term relationship with suppliers and provide support to enhance the quality of their suppliers. Evan and Lindsay (2002, p. 99) found that a reduced supply base decreases the variation coming into the processes, thus reducing scrap, rework, and the need for adjustment to accommodate this variation." In oil industry, optimizing supplier relationships lead to reduce refining maintenance costs, eliminating defects, and conducting risk-based inspection. Slaight (1999) opined that through effective suppliers' relationship, companies can reduce procurement cost by $10 \%$ to $15 \%$.

Learning (Training and Education): Learning is about, the organizational capability to recognize and nurture the development of its skills, abilities, and knowledge base. According to Deming (1986), learning is a continual process for the purpose of expanded knowledge with its own merit. Huq and Martin (2000 p. 97) identified that education and training of workforce is the basic quality principle." Roth and Jackson (1995) considered operational competence of service firms as their organizational knowledge. Barret (1999) noted that learning culture fosters innovative thinking and collaborative system. Authors argue that 
superior Organisational performance depends on learning. Therese (2007) experienced positive impact of training and development on individuals and the organization to create value for customers. Organizations undergoing organizational transformation undertake learning in order to develop the organizational capabilities which are required for survival and success in the new context. Organizational capabilities represent the ability of an organization to perform a coordinated set of activities utilizing organizational resources, for the purpose of achieving a particular end result‘ (Helfat \& Peteraf, 2003: 999). Organizations in developing economies need to develop two types of organizational capabilities. First, they need to develop the basic operational capabilities required for survival in a market economy, but missing in a centrally planned economy, for instance marketing, finance, HR and information sharing (Filatotchev et al 2003; Hitt et al 2000; Peng, 2000; Puffer, 1994). Second, since the institutional environment in transition economies is unstable, they need to develop the capability to respond quickly to changing competitive conditions, described as strategic flexibility by Hitt et al (1998).

Process Management: Process management is set of methodological and behavioral practices emphasizing the management of process, or means of actions, rather than results Anderson et al. (1994). Process management emphasizes adding value to processes increasing quality levels, and raising productivity per employee. Process management also involves analysing and redesigning processes to remove problems and inefficiencies in the organization (Dahlgaarde et al 2002; Deming, 1986). According to them, the greatest advantage of process management is that it helps an organization to understand how things are really done, revealing problems and bottlenecks. Process management also helps to reduce lead times, decrease costs, improve overall quality, and increase customer and employee satisfaction. Process measurement is a key to the success of any process improvement and can increase understanding of how processes are operating.

Continuous improvement: The concept of continuous improvement implies constant improvement in the processes, products and services. Deming (1986) stressed the organizations to improve continuously the products and services. Anderson et al (1994) identified that continuous improvement is based on process management practices that yield incremental improvement and innovations in products, services, and processes. It is argued that the values driving CI are basically the values that ensure commitment to customer satisfaction. Juergensen (2000) viewed continuous improvement as an initiative that enhances success and decreases failures. Bessant et al (1994) found it as a process of continuous incremental innovation. Overall performance is associated with continuous improvement 
(CI). According to TQM theory, the best way to improve organizational output is to continually improve performance (Corbett and Rastrick, 2000).

Employee involvement and participation: The impact of employee support in achieving quality goals has already been praised by many authors (Ahire et al., 1996; Black and Porter, 1996; Blackburn and Rosen, 1993; Clemmer, 1990; Creech, 1994; Evans and Lindsay, 2002; Kanji and Asher, 1993; Oakland, 2000; Sun, 2000; Thiagarajan and Zairi, 1997). Middle management and shop floor employees need to be involved in the organisational process as major internal stakeholders. They need to be motivated to rise up to the challenge of adopting TQM through appropriate training packages as well as work-based incentives. Oakland (1989) concluded that employees are a source of ideas and their competency need to be harnessed to transform these ideas into reality. Deming (1986) and Feigenbaum (1983) strongly supported employees ${ }^{6}$ participation in decision making. Researchers and quality experts have concluded that employee fulfillment is a multidimensional concept based on employees ${ }^{6}$ total satisfaction from work environment and manifests in job satisfaction, pride of workmanship, commitment, continuous learning and innovation, and results in enhanced quality of product, processes, and services to the customers (Locke, 1976).

Customer Satisfaction: Customer satisfaction is at the heart of TQM philosophy. A proactive approach to responding to changing customer" needs are vital to attract and retain customers. By close interaction with customers, organizations can determine customers ${ }^{\star}$ changing requirements, trends and use them as yardstick with their competitors (Vavra, 2002). Parzinger and Nath (2000, p.356) clearly stated that in TQM environment the job is not done until the customer is satisfied."Anderson et al (1994) noted that customer satisfaction is exemplified by customer driven focus. Literature review highlights that internal quality practices of organizations affect customer satisfaction (Nilsson et al 2001). The research found that worker awareness and mindset is positively related to customer satisfaction.

Based on the study of literature, following hypotheses emerge:

H 1. Visionary leadership has positive relationship with internal and external cooperation.

H 2. Visionary leadership has positive relationship with learning.

H 3. Internal and external cooperation has positive relationship with process management.

H 4. Learning has positive relationship with process management.

$H$ 5. Process management has positive relationship with continuous improvement.

H6. Process management has positive relationship with employee involvement and participation. 
H 7. Continuous improvement has positive relationship with customer satisfaction.

H8. Employee involvement and participation has positive relationship with customer satisfaction.

\section{METHODS}

Instrument Development: The present study used the questionnaire developed by Douglas and Fredendall (2004). The questionnaire was designed to suit the research objectives stated. Information obtained through the questionnaire is complemented by a second level of investigation (qualitative survey) in the form of semi-structured interviews. After a comparison of different rating scales, the researcher selected an approach that he believed would make the questionnaire easy for the respondents to answer, and thus encourage them to participate. Therefore; the questionnaire developed uses a Five points Likert scale from strongly agree (5) to strongly disagree (1) was adopted for the study.

Pilot Testing of Instrument: To validate the instrument, a sample of 6 executives, managers, and experts in TQM was used in the pilot testing. The Cronbach's alpha for different variable. This indicated that the reliability of multi-item scales corresponding to them ranged between 0.827 and 0.912 . Generally, a reliability coefficient of 0.70 or more is considered to be good (Nunnally, 1967).

Sample and Data Collection: Combination of methods was used in order to improve both the reliability and validity of the data gathered. 45 questionnaires were personally distributed to quality-related managers and collected by hand in Libya. A complete set of questionnaire including a covering letter accompanied the questionnaire. Forty two out of Forty five questionnaires were returned sufficiently completed, that gave us a response rate of approximately $93.33 \%$. Semi-Structured Interviews with 6 case studies were conducted with managers represented different functional areas of the LOGCs. In-depth open interview with 2 case studies were conducted.

Validity of Instrument: The researcher believes that the instrument used in this research has content validity, since the development of the measurement items was based primarily on an extensive review of the literature and detailed evaluations carried out by academicians and practitioners. In addition different studies have used the measuring scales and validated the items of the instrument (Ahire et al 1996; Quazi et al 1998; Rao et al 1999; Saraph et al 1989). The content validity of the instrument of this study was established using two stages. First, for face validity, the instrument was presented to a panel of two quality experts who approved that the items measure the concept. In the second step, the questionnaire was given 
to four experts, two in academic positions and two managers working in LOGCs to ensure that the participants understand the items in the questionnaire. The response was affirmative and no ambiguity was experienced in understanding the items in the instrument. For construct validity, confirmatory factor analysis was undertaken for this study to validate the factors used in the instrument.

Data Analysis: Both descriptive and inferential statistics has been used to analyze the data. Statistical Package for Social Sciences (SPSS-version 17) software has been used in the analysis.

\section{RESULTS AND ANALYSIS}

Results of descriptive statistics: All the constructs drew general agreement with regard to the responses table (1). The results, based on mean score and standard deviation, reflect respondents' general agreement to the dimensions of the model.

Results of reliability and validity of data: The Cronbach's alpha for individual variables indicated that the measure is compositely reliable and internally consistent as recommended by Nunnaly (1978).

Results of test of normality of data: The results of multi-collinearity analysis indicated that Tolerance levels (< or equal to 0.01) and Variation Inflation Factor (VIF) value (below 10) are within acceptable range. The values of Durbin Watson for all variables are also within limits ((between 1.5 and 2.7). The tests exhibit that multi-collinearity problem does not exist. Results of factor analysis: For construct validity, to validate the underlying structure of the model, confirmatory factor analysis was conducted. Prior to the conduct of confirmatory factor analysis, Kaiser-Meyer-Olkin (KMO) static and Bartlett's Test of Sphericity was performed. The KMO value $(\mathrm{KMO}=0.875)$ indicated that the degree of common variance among the seven variables was marvelous (Malhotra, 2004). The Bartlett's test of sphericity indicated a Chi square 7.205 with an observed significance level of $p<.001$. Based on the results, it was inferred that the relationship between the variables was strong and appropriate for factor analysis. These factors explained $72 \%$ of variance.

Results of Correlation Analysis: To determine the relationship between variables, correlation analysis was done. Table 2 indicates that all factors have positive and significant relationship. Results reflect that the correlation between variables is significant $(\mathrm{p}<0.001)$.

Results of Regression Analysis: The result of regression equation based on path analysis is reflected in Table 3 . The variable of Visionary leadership positively and significantly predicts in Internal and external cooperation, $\mathrm{F}(1,288)=176.733, \mathrm{p}<0.01$, Beta $=0.647, \mathrm{p}<0.01$, $\mathrm{R}$ 
Square $=0.512$; continuous improvement, $F(1,288)=158.929, \mathrm{p}<0.01$, Beta $=0.635, \mathrm{p}<$ 0.01 , R Square $=0.387$; and Customer Satisfaction, F $(1,288)=168.877, p<0.01$, Beta $=$ $0.555, \mathrm{p}<0.01, \mathrm{R}$ Square $=0.340$. The results leadership's commitment to the total quality management creates enabling environment in the organization and fosters employee involvement and participation; customer satisfaction promote continuous improvement. Customer satisfaction was regressed on predicting variables of employee involvement and participation and continuous improvement. The combination of these variables significantly predicts customer satisfaction, $\mathrm{F}(2,287)=73.857, \mathrm{p}<0.01($ Beta $=0.555, \mathrm{p}<0.01)$ for employee involvement and participation, $($ Beta $=0.631, \mathrm{p}<0.01)$ for continuous improvement. The R Square $=0.340$ and 0.399 depicts that these variables explain $34 \%$ and $39.9 \%$ of variance in the customer satisfaction.

\section{DISCUSSION}

The main objective of the study was to empirically examine the TQM practices in LOGCs. The results of the study provided strong empirical support to the Deming Management Model. The path analysis also provided empirical evidence for the support of the theoretical relationship proposed in 8 hypotheses. The crucial role of visionary leadership in pursuing companywide quality policies has been well established.

Visionary leadership pursues a partnership with employees, customers, and other stakeholders. The study indicated positive and statistically significant relationship with customer satisfaction. Kanji and Moura (2001) acknowledged that outstanding leaders can contribute heavily to total quality by creating inspiring innovative environment.

Employee involvement and participation manifest in individual's job satisfaction, job commitment and the pride of accomplishment of products, services quality, and possession of knowledge for initiating improvement in processes. The study found positive and statistically significant relationship with customer satisfaction. Sureschandar et al., (2001) found evidence of strong relationships between employee perception of employee well-being and customer perception of service quality and satisfaction. Rienzer and Testa, (2003) acknowledged that the benefits for internal customers' satisfaction (employee satisfaction) provide greater support for continuous improvement.

Continuous improvement is one of the essential factors in TQM success. Rapid changes in technology and customers' requirements require a flexible approach toward aligning organizational products, processes and services to meet and exceed ever changing customers‘ 
needs. The results highlight positive and statistically significant relationship with customer satisfaction.

The findings of this study highlight the important role of the leadership in driving the total quality management practices in LOGCs. The findings supported the studies regarding the dominant role of leadership in planning and implementing TQM practices (Pun \& Hui, 2002; Tata \& Prasad, 1998; Singh et al., 2007; Zairi, 1994).

The findings support the idea that effects of visionary leadership on customer satisfaction is dependent on creating and sustaining a quality focused organizational culture (Waldman \& Gopalakrishnan, 1996).

\section{CONCLUSIONS}

The aim of the study was to examine the total quality management practices of Libyan Oil and Gas Companies (LOGCs). The results have reflected that these organizations implement TQM practices. There is, however, lack of a structured mechanism for self evaluation of these practices. These companies need to focus on these important issues to identify gaps, and strive for continuous improvement to achieve competitiveness.

The study provides a significant contribution in the application of Deming Management Model to oil industry in a different cultural context. The sound theoretical and empirical support for different variables in the oil and gas industry advocates that researchers and academician should include these dimensions in the study and research. The study indicates that Deming Management Model is equally applicable to oil industry and reinforces the belief in the effectiveness of the Model.

The success of TQM practices depend on a supporting organizational culture. In Libyan business environment, the cultural dimension becomes even more important for the success of TQM initiatives. The response to TQM initiatives in different cultural context has been studied. There is a need to further study the cultural dimensions in Libyan organizations and its compatibility to TQM philosophy, identifying the bottlenecks for adaptation of this philosophy of change and initiating the required response to enhance organizational competitiveness.

The model also offers opportunities for its further development based on the study and exploration of additional paths. In order to manage quality dimensions effectively, identification of barriers in planning and implementation of TQM practices is essential in Libyan organizations. This aspect should be investigated with a view to adopt a proactive response strategy to eliminate these barriers to realize the objectives of TQM practices. 
This study offers strong evidence of continued significance of quality management as a priority issue for developing countries to remain competitive in domestic and global markets. The results of this research indicate that quality management practices have been well embedded in the managerial practices of organizations in developing countries.

\section{REFERENCES}

Ahire, S. L., Golhar, D. Y., \& Waller, M. A. (1996). Development and Validation of TQM Implementation Constructs. Decision Sciences, 27(27): 23-56.

Anderson, J. C., Rungtusanatham, M., \& Schroeder, R. G. (1994). A Theory of Quality Management Underlying the Deming Management Method. Academy of Management Review, 19(3): 472-509.

Anderson, J., Rungtusanatham, M., Schroeder, R., \& Devaraj, S. (1995). A Path Analytic Model of A Theory of Quality Management Underlying the Deming Management Method: Preliminary Empirical Findings. Decision Sciences, 26: 637-658.

Anderson, M., \& Sohal, A. S. (1999). A Study of Relationship Between Quality Management Practices and Performance in Small Business. International Journal of Quality \& Reliability Management, 16 (9): 859-77.

Barrett, F. (1999). Creating Appreciative Learning Cultures. Organizational Dynamics, Autumn: 36-49.

Bessant, J., Caffyn, S., Gilbert, J., Harding, R., \& Webb, S. (1994). Rediscovering Continuous Improvement. Technovation, 14 (1): 17-29.

Black, S.A, Porter, L.J (1996) "Identification of the Critical Factors of TQM", Decision Sciences, vol. 27, no.1, pp.

$1-21$

Blackburn, R. and Rosen, B. (1993), Total quality and human resource management: lessons learned from Baldbridge Award-winning companies", Academy of Management Executive, Vol. 7 No. 3, pp. 49-66.

Brocka, B., \& Brocka, M.S. (1992). Quality Management: Implementing the Best Ideas of the Masters, Richard D. Irwin, Homewood, IL.

Clemmer, J. (1990) Firing on All Cylinders. Judy Piatkus Publishers, London

Cook, L. S., \& Verma, R. (2002). Exploring the Linkages Between Quality System, Service Quality, and Performance Excellence: Service Providers' Perspectives. Quality Management Journal, 9(2): 44-56.

Corbett L. M. and Rastrick K. N., 2000: Quality performance and organisational culture: A New Zealand study. International Journal of Quality \& Reliability Management 17 (1), 1426. 
Creech, B. (1994). The Five Pillars of TQM: How to make Total Quality Management Work for You. New York, NY: Truman Talley Books/Dutton.

Dale, B. G. (2003). Managing Quality (4th ed.). Hertfordshire: Prentice Hall. 676 p.

Deming, W. E. (1986). Out of the Crisis, Cambridge University Press, Cambridge. 508 p.

Deming, W. E. (1993). The New Economics for Industry, Government, Education. Cambridge: Massachusetts Institute of Technology, Center for Advanced Engineering Study.

Dahlgaard F. F.; Poksinska, B.; Antoni, M. The state of ISO 9000 certification: a study of Swedish organizations. The TQM Magazine, v. 14, n. 5, p. 297-306, 2002.

Evans, J. R., \& Lindsay, W .M. (2002). The Management and Control of Quality (5th ed). South-Western, USA.

Feigenbaum, A. V. (1983). Total Quality Control (3rd Ed) New York, McGraw-Hill. 896 p.

Filatotchev, I., Wright, M., Uhlenbruck, K., Tihanyi, L. \& Hoskisson, R. E. Governance, organizational capabilities, and restructuring in transition economies. Journal of World Business. 2003, 38, 331-47.

Flynn, B. B., Schroeder, R. G. and Sakakibara, S. (1994), A framework for quality management research and an associated measurement instrument", Journal of Operations Management, Vol. 11 No. 4, pp. 339-366.

Flynn, B. B., Schroeder, R. G. and Sakakibara, S. (1994), A framework for quality management research and an associated measurement instrument", Journal of Operations Management, Vol. 11 No. 4, pp. 339-366.

Hitt, M. A., Dacin, M. T., Levitas, E., Arregle, J.-L. \& Borza, A. Partner selection in emerging and developed market contexts: Resource-based and organizational learning perspectives. Academy of Management Journal. 2000, 43, 449-67.

Hitt, M. A., Keats, B. W. \& DeMarie, S. M. Navigating in the new competitive landscape: Building strategic flexibility and competitive advantage in the 21 st century. Academy of Management Executive. 1998, 12, 22-42.

Huq, Z., \& Martin, T. (2000). Workforce cultural factors in TQM/CQI implementation in hospital. Health Care Management Review, 25(3), 80-103.

Helfat CE, Peteraf MA. 2003. The dynamic resource-based view: Capability lifecycles. Strategic Management Journal 24: 997-1010.

Juergensen, T. (2000). Continuous Improvement: Mindsets, Capability, Process, Tools and Result. The Juergensen Consulting Group, Inc., Indianapolis, IN. 598 p.

Juran, J. M. (1988). Juran on Planning for Quality. Cambridge MA: Productivity Press. A Life Cycle Approach (5th ed), Homewood, IL, Irwin. 634 p. 
Kanji, G.K. and Asher, M. (1993) Total Quality Management Process-A Systematic Approach. Advances in Total Quality Management Series. Carfax Publishing, Abingdon.

Kanji, G. K., \& Moura, P. (2001). Measuring Leadership Excellence. Total Quality Management, 12(6): 701-718.

Locke,E.A. (1976). The nature and causes of job satisfaction. In M.D. Dunnette (Ed.), Handbook of industrial and organizational psychology (pp.1297-1349). Chicago: Rand McNally

Mann R. S, Kehoe D. F. (2004). The Implementation of Total Quality Management (paper 2). Quality World Technical Supplement: Vol. 12 No. 2 pp. 11-23.

Newall D, Dale BG. (2002), The introduction and development of a quality improvement process: a study”. International Journal of Production Research

Nilsson L., Michael D. Johnsonb, ${ }^{*}$, Anders Gustafssonc, The impact of quality practices on customer satisfaction and business results: product versus service organizations, Journal of Quality Management, vol. 6, no. 1, pp. 5-27, 2001

Nunnally, J.C. 1978. Psychometric theory, 2d. ed., McGraw-Hill, New York.

Oakland, J.S. (1989), Total Quality Management, Butterworth- Heinemann, Oxford.

Oakland, S. and Oakland, J.S. (2001), -Current people management activities in world-class organizations", Total Quality Management, Vol. 12 No. 6, pp. 773-88.

Oakland, J. (2000),- Fotal Quality Management-Text with Cases", 2nd Edition Parzinger, M.J., \& Nath, R., 2000. A study of the relationships between total quality management implementation factors and software quality. Total Quality Management, 11(3), 353-371.

Peng, M. W. Business strategies in transition economies. Thousand Oaks, CA: Sage, 2000.

Puffer, S. M. Understanding the bear: A portrait of Russian business leaders. Academy of Management Executive. 1994, 8, 41-54.

Puffer, S.M. and McCarthy, D.J. (1996) A framework for leadership in a TQM context, Journal of Quality Management, Vol.1, No.1, pp109-130

Pun, K., \& Hui, I. (2002). Integrating the safety dimension into quality management systems: a process model. Total Quality Management, 13(3), 373-391.

Quazi, H.A., Jemangin, J., Kit, L.W., Kian, C.L., 1998. Critical factors in quality management and guidelines for self-assessment, the case of Singapore, Total Quality Management 9 (1) 35-55 
Rao, S. S., Solis, L. E., \& Raghunathan, T. S. (1999). A Framework for International Quality Management Research: Development and Validation of a Measurement Instrument. Total Quality Management, 10(7): 1047-1075.

Roth, A. V. and Jackson, W. E. (1995). Strategic Determinants of Service Quality and Performance: Evidence from the Banking Industry. Management Science, 41: 1720-733.

Rungtusanatham, M., Forza, C., Filippini, R., \& Anderson, J. (1998). A replication study of theory of quality management underlying the Deming management method: Insights from an Italian context. Journal of Operations Management, 17, 77-95.

Saraph, J. V., Benson, P. G., \& Schroeder, R. G. (1989). An Instrument for Measuring the Critical Factors of TQM. Decision Sciences, 20(4): 810-29.

Singh, P.J, Chua, M.W., \& Sum, C.C. (2007). Deming management method: Applying theory to public sector organizations and testing refinements. [Online] Available:

http://www.ecom.unimelb.edu.au/downloads/nus_symposium/Singh_paper.pdf

Slaight, T. H. (1999). Strategic Sourcing: Not a Squeeze Your Vendor Process. Telecommunication, 33(3): 59-62.

Sousa, R., \& Voss, C. (2002). Quality management re-visited: a reflective review and agenda for future research. Journal of Operations Management, 20(1), 91-109.

Sun, H. (2000), A comparison of quality management practices in Shanghai and Norwegian manufacturing companies", International Journal of Quality \& Reliability Management, Vol. 17 No. 6, pp. 636-660.

Sureshchandar, G.S., Rajendran, C., \& Kamalanabhan, T.J. (2001). Customer perceptions of service quality: a critique. Total Quality Management, 12(1), 111-124.

Taguchi, G. (1979). Introduction to Off-Line Quality Control. Japanese Standards Association. Tokyo. 857 p.

Therese A.J. (2007).Total Quality Management and performance, the role of organization support and co-worker support. International Journal of Quality and Reliability Management. Vol. 24, No. 6, pp 617-627.

Thiagarajan, T. and Zairi, M. (1997), “A review of total quality management in practice: understanding the fundamentals through examples of best practice applications, part 1" , The TQM Magazine, Vol. 9 No. 4, pp. 270-86

Tata, J., \& Prasad, S. (1998). Cultural and Structural Constraints on Total Quality Management Implementation. Total Quality Management, 9 (8): 703-10.

Vavra, T. G. 2002. Customer Satisfaction Measurement Simplified: A Step-by-Step Guide for ISO 9001:2000 Certification. Milwaukee; WI: ASQ Quality Press 
Waldman, D. A., \& Gopakakrishnan, M. (1996). Operational, Organizational, and Human Resource Factors Predictive of Customer Perceptions of Service Quality. Journal of Quality Management, 1(1): 91-107.

Wilsey, M. D. (1995). Leadership and Human Motivation in the Workplace. Quality Progress, 28(11): 85-88.

Zairi, M. (1994). Leadership in TQM Implementation: Some Case Examples. The TQM Magazine, 6(6): 9-16.

Zhang, Z. (2000). Developing A Model of Quality Management Methods and Evaluating Their Effects on Business Performance. Total Quality Management, 11(1): 129-37 


\section{Figures Captions:}

Fig.1. Proposed theory framework

\section{Tables Titles:}

Table1. Descriptive statistics

Table2. Correlation Matrix

Table3. Path Analysis 


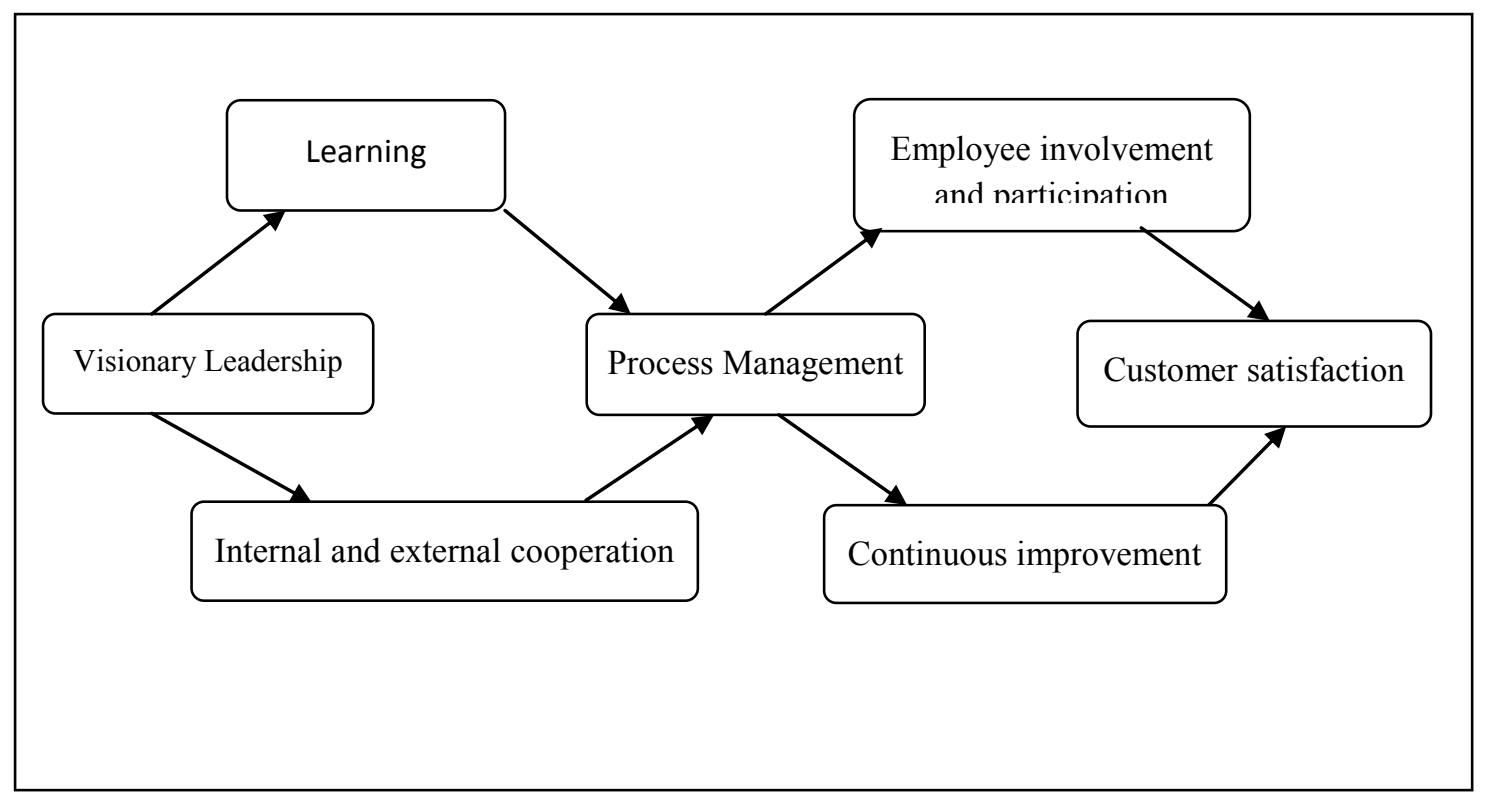

Table1. Descriptive statistics

\begin{tabular}{lccc}
\hline Constructs & Mean & STDV & $\begin{array}{c}\text { Cronbach's } \\
\text { alpha }(\boldsymbol{\alpha})\end{array}$ \\
\hline Visionary leadership & 4.03 & 0.643 & 0.853 \\
Internal and external cooperation & 3.96 & 0.664 & 0.822 \\
Learning & 3.71 & 0.682 & 0.875 \\
Process Management & 4.16 & 0.670 & 0.863 \\
Continuous improvement culture & 4.38 & 0.524 & 0.842 \\
Employee involvement and participation & 3.85 & 0.612 & 0.865 \\
Customer Satisfaction & 4.32 & 0.360 & 0.786 \\
\hline
\end{tabular}

Fig.1. Proposed theory framework

Table2. Correlation Matrix

\begin{tabular}{lcccccc}
\hline Variables & VL & IEC & PM & CI & EIP & CS \\
\hline Visionary Leadership (VL) & & & & & & \\
Internal and external Cooperation (IEC) & $* 0.647$ & & & & & \\
Learning (LG) & $* 0.555$ & $* 0.437$ & & & & \\
Process Management (PM) & $* 0.635$ & $* 0.248$ & $* 0.298$ & & & \\
Continuous improvement culture (CI) & $* 0.242$ & $* 0.555$ & $* 0.608$ & $* 0.631$ & & \\
Employee involvement and participation (EIP) & $* 0.546$ & $* 0.618$ & $* 0.635$ & $* 0.608$ & $* 0.622$ & \\
Customer Satisfaction (CS) & $* 0.175$ & $* 0.179$ & $* 0.213$ & $* 0.195$ & $* 0.186$ & $* 0.205$ \\
\hline *Correlation is significant at $\mathrm{p}<0.01$ level (2- tailed) & & & & & &
\end{tabular}


Table3. Path Analysis

\begin{tabular}{|c|c|c|c|c|}
\hline Path & $\overline{\mathbf{R}^{2}}$ & Beta & T value & Significance \\
\hline $\begin{array}{l}\text { Visionary leadership to internal and } \\
\text { external cooperation }\end{array}$ & 0.512 & 0.647 & 13.872 & $* * 0.001$ \\
\hline Visionary leadership to learning & 0.387 & 0.635 & 13.118 & $* * 0.001$ \\
\hline $\begin{array}{l}\text { Internal and external cooperation to } \\
\text { process management }\end{array}$ & 0.340 & 0.555 & 11.048 & $* * 0.001$ \\
\hline Learning to process management & 0.340 & 0.555 & 12.687 & $* * 0.001$ \\
\hline $\begin{array}{l}\text { process management to Employee } \\
\text { involvement and participation }\end{array}$ & 0.399 & 0.631 & 13.102 & $* * 0.001$ \\
\hline $\begin{array}{l}\text { Process management to Continuous } \\
\text { improvement }\end{array}$ & 0.370 & 0.608 & 12.832 & $* * 0.001$ \\
\hline $\begin{array}{l}\text { Employee involvement and participation } \\
\text { to Customer Satisfaction }\end{array}$ & 0.254 & 0.307 & 4.213 & $* * 0.001$ \\
\hline $\begin{array}{l}\text { Continuous improvement to Customer } \\
\text { Satisfaction }\end{array}$ & 0.315 & 0.139 & 2.222 & $* * 0.001$ \\
\hline
\end{tabular}

Significance level $=* *, p<0.001$ 